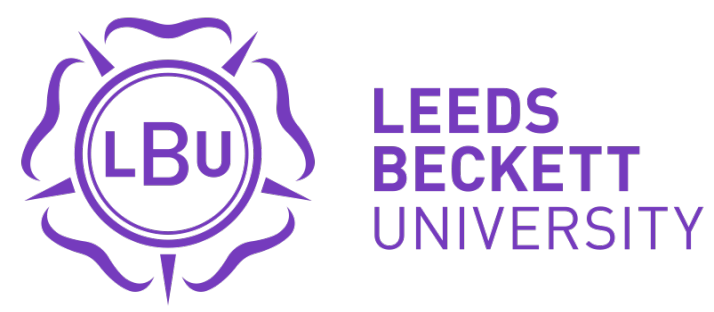

Citation:

Kuokkanen, $\mathrm{H}$ and Sun, W (2016) SOCIAL DESIRABILITY AND CYNICISM: BRIDGING THE ATTITUDE-BEHAVIOR GAP IN CSR SURVEYS. In: Research on Emotion in Organizations. Emerald, pp. 217-247. ISBN 978-1-78560-998-5 DOI: https://doi.org/10.1108/S1746979120160000012008

Link to Leeds Beckett Repository record:

https://eprints.leedsbeckett.ac.uk/id/eprint/3089/

Document Version:

Book Section (Accepted Version)

The aim of the Leeds Beckett Repository is to provide open access to our research, as required by funder policies and permitted by publishers and copyright law.

The Leeds Beckett repository holds a wide range of publications, each of which has been checked for copyright and the relevant embargo period has been applied by the Research Services team.

We operate on a standard take-down policy. If you are the author or publisher of an output and you would like it removed from the repository, please contact us and we will investigate on a case-by-case basis.

Each thesis in the repository has been cleared where necessary by the author for third party copyright. If you would like a thesis to be removed from the repository or believe there is an issue with copyright, please contact us on openaccess@leedsbeckett.ac.uk and we will investigate on a case-by-case basis. 


\title{
Social Desirability and Cynicism: Bridging the Attitude-Behavior Gap in CSR Surveys
}

\author{
Henri Kuokkanen and William Sun
}

\begin{abstract}
ABSTRAT
Purpose - Many consumer-focused corporate social responsibility (CSR) studies suggest a positive link between the responsibility demon- strated by a company and consumers' intention to favor the company in their purchases. Yet an analogous causal effect between corporate social and financial performances is not evident. This chapter conceptualizes how social desirability and cynicism contribute to the discrepancy between consumers' attitudes and their actual purchase behavior, and analyzes why consumer choices indicated in surveys do not consistently convert into actions.
\end{abstract}

Methodology/approach - We develop a conceptual framework based on hybrid choice modeling to estimate the impact of two new variables, Corporate Social Desirability and Corporate Social Cynicism, on CSR research. The model presented synthesizes research findings from the fields of CSR and psychology with a discrete choice methodology that allows inclusion of psychological aspects as latent variables.

Findings - The goal of the framework is to bridge the gap between choices stated by consumers in CSR surveys and their actual choices by quantifying and extracting the effects of biases that otherwise threaten the validity of such survey results. As the next step, the practical value of the model must be evaluated through empirical research combining a CSR choice study with social desirability and cynicism measurement.

Originality - The framework proposes a novel way of controlling CSR surveys for potential biases created by social desirability and cynicism and enables quantification of this impact, with potential application to other fields where psychological aspects may distort research results. Future empirical evidence based on the framework may also offer new insights into the mechanisms by which the two biases distort findings.

Keywords: Attitude-behavior gap; consumer choice; corporate social responsibility; cynicism; discrete choice model; social desirability

A business case for CSR appears extant (Carroll \& Shabana, 2010). A dec- ade ago, multiple studies already suggested that customers are willing to champion companies whose values match theirs (Bhattacharya \& Sen, 2003; Mohr \& Webb, 2005; Vogel, 2005), and the theme is also evident in more recent research (Koschate-Fischer, Stefan, \& Hoyer, 2012; Stanaland, Lwin, \& Murphy, 2011). Consulting studies offer further support. According to Edelman (2012), 58\% of consumer studies claimed that price and quality being equal, social purpose becomes the most important factor in brand selection - an increase of $26 \%$ from 2008 . Nielsen (2014) found that $55 \%$ of consumers "will pay extra for products and services from com- panies committed to positive social and 
environmental impact" (p. 2) and that 52\% are checking product packaging for sustainability information. Accenture and United Nations Global Compact (2014), in a worldwide consumer study, discovered that $27 \%$ of European consumers "always" or "often" review sustainability aspects when making purchase decisions, while in Asia and Latin America 39\% of consumers do so. According to the same study, consumers would be motivated to consider sustainability in their decisions if companies provided more tangible responsibility out- comes. While the potential of responsibility to shape consumer decisions has been evident for some time, the evidence suggests a growing trend and emphasizes the need for companies to understand the true nature of consu- mer demand for CSR.

Despite this apparent consumer interest in responsibility, the business case remains elusive. Since the 1970s, scholars have searched for a link between Corporate Social Performance (CSP) and Corporate Financial Performance (CFP), but this has proven an arduous task. Despite 159 indi- vidual studies counted by Peloza (2009), there is still no consensus on whether a causal link exists. A widely referenced meta-analysis by Orlitzky, Schmidt, and Rynes (2003) found a mutual relationship between CSP and CFP; in other meta-analyses, $\mathrm{Wu}$ (2006) discovered an average positive correlation between social and financial performances, while Margolis, Elfenbein, and Walsh (2009) found no financial disadvantage for investing in CSP but noted that previous financial performance has an equally strong link with future social performance. On the other hand, Vishwanathan (2010) reported a weaker relationship than earlier findings suggested: the relatively small correlation remaining between the two variables after accounting for joint causation was mediated by aspects of corporate strat- egy. While the evidence suggests an overall positive correlation between CSP and CFP, the direction of causality remains unclear: Does responsibil- ity improve financial performance, or do well-performing companies have more room to operate in a responsible manner?

In analyses of individual industries, as opposed to meta-analyses, recent studies reinforce this mixed, though mostly positive, link between CSP and CFP. The variability in results is attributed to explanations such as stake- holder influence capacity (Barnett \& Salomon, 2012; Peloza \& Papania, 2008) and the competitiveness of the industry in which a company operates (Kemper, Schilke, Reimann, Wang, \& Brettel, 2013). Interestingly, Michelon, Boesso, and Kumar (2013) suggested that responsibility linked to stakeholder expectations enhances financial performance. While a multitude of factors likely contribute to the relationship between these two variables, one question stands out: why does the ostensibly strong and upward-trending consumer interest in CSR, suggested in both academic and consulting studies, not result in real consumer actions and clearly enhanced financial performance of responsible companies? This chapter approaches the topic from the aspect of human psychology, particularly the difference between reallife actions and stated survey responses, and aims to bridge the gap between stated and real choices to improve the validity of consumer CSR research.

Social desirability (SD) bias, or the tendency to answer questions in a way considered acceptable or expected, is an important problem in all social science studies involving respondents self-filling questionnaires (Arnold \& Feldman, 1981). Since CSR is often perceived as ethically "the right thing to do," a desirability effect can overemphasize responsible char- acteristics in surveys and bias the results, creating an attitude-behavior gap (Roberts, 1996). Beckmann (2007) suggested that the type of methodology chosen for a consumer CSR study will determine whether the outcome is positive or negative in terms of the potential effect of responsibility on con- sumption, with quantitative methods leading to a positive link. However, few authors have addressed this issue in their studies. 
A lack of trust in CSR initiatives may be rooted in consumer skepticism or cynicism toward the underlying motivations and significantly reduce the value CSR can bring to a company (Groza, Pronschinske, \& Walker, 2011; Pomering \& Dolnicar, 2008; Skarmeas \& Leonidou, 2013). Skepticism and cynicism must be differentiated: According to Kanter and Mirvis (1986) "skeptics doubt the substance of communications; cynics not only doubt what is said but the motives for saying it" (p. 301). While it is possible to alleviate the mostly short-term effects of skepticism through well-designed communication of solid evidence, a cynical attitude can contribute to an "undesirability" bias toward responsibility and lead to a blanket rejection of all CSR aspects in a survey.

In this chapter, we maintain that the joint effects of SD and cynicism, both largely neglected in CSR research, can blur the results of consumer surveys and contribute to the discrepancy between consumer statements and actions noted in research results. To bridge the gap between stated and real choices, or the attitude-behavior gap (Carrigan \& Attalla, 2001), we propose a conceptual framework that includes two new variables in CSR research to control survey results for their effects: Corporate Social Desirability (CSD) and Corporate Social Cynicism (CSC). Both variables measure the effect of these psychological aspects on stated consumer choices. Our hybrid choice modeling framework aims to increase the validity of CSR consumer surveys by segregating the impact of biases created by SD and cynicism from the results, and thus provide more conclusive evidence of the impact CSR may have on purchase decisions.

\section{SOCIAL DESIRABILITY AND CYNICISM AS SOURCES}

\section{FOR BIAS}

SD bias is the tendency of survey respondents to present themselves in a way that is more favorable than their actual behavior would suggest with reference to social norms (Fernandes \& Randall, 1992). It is evident in all studies related to business ethics, particularly when self-reported ethical attitudes come into question. A wide range of techniques have been devel- oped to counter this phenomenon, with varying interpretations of their effi- ciency (De Jong, Pieters, \& Fox, 2010; Fisher, 1993; Fisher $\&$ Tellis, 1998; Van de Mortel, 2008). Warner (1965) proposed randomized response techniques as a solution to SD bias, a solution still in active use and employed recently by De Jong et al. (2010). Gordon (1987) suggested giving respon- dents more detailed information about the task as a means to reduce bias. Fisher and Tellis (1998) maintained that indirect questioning is a superior alternative for achieving less biased survey results. Steenkamp, de Jong, and Baumgartner (2010) proposed that in a low-demand situation (such as an anonymous questionnaire conducted online), SD bias is likely to be unconscious, and they suggested that researchers encourage reflection over impulse from respondents to counter instinctive behavior. Tourangeau and Yan (2007) summarized several techniques to reduce SD bias, including randomized response, bogus pipeline, self-administration of questionnaires, and collection of data in private. They further recommended priming respondents for honesty, though de Jong et al. did not find that priming improved response quality. Despite commonplace application, there is no clear consensus on the efficiency of these techniques in reducing SD in responses.

\section{Scales for Measuring Social Desirability Bias}

Crowne and Marlowe (1960) created the first widely accepted scale intended to 
measure SD bias. Known as the Marlowe-Crowne SD scale, the original version presented respondents with 36 statements deemed by an expert panel to represent situations that involve desirable behavior. The respondents accept or reject the statements; rejecting a statement widely considered to be accepted in real life, or vice versa, reveals a desirability bias. As noted by Kuncel and Tellegen (2009), the use of Likert scales instead of true/false choice in measuring SD bias is not preferable; extreme answers are often not perceived as desirable and thus a Likert-scale would fail to recognize the degree of the bias. As the original Marlowe-Crowne scale was considered too long to be feasible for many studies, several shorter or alternative versions of the scale were developed (Reynolds, 1982; Sto" ber, 2001; Strahan \& Gerbasi, 1972); these revisions also updated the questions to fit modern situations. While there is support for the usefulness of these shorter scales (Andrews \& Meyer, 2003; Blake, Valdiserri, Neuendorf, \& Nemeth, 2006; Greenberg \& Weiss, 2012; Loo \& Thorpe, 2000), there is disagreement over their validity (Barger, 2002; Beretvas, Meyers, \& Leite, 2002; Johnson, Fendrich, \& Mackesy-Amiti, 2012).

Another leading scale in measuring SD is the Balanced Inventory of Desirable Responding (BIDR), developed by Paulhus (1984). Paulhus divided SD bias into two separate constructs, self-deception and impression management, and suggested the existence of conscious and unconscious levels of desirable answering. Later Paulhus (2002) advanced his conceptua- lization to encompass two main constructs of desirability bias, moralistic and egoistic response tendencies; this model became known as the Paulhus Deception Scales (PDS). Moralistic and egoistic tendencies can both include conscious (deliberate impression management) and unconscious (self-deceptive exaggeration) styles, leading to four different subcategories of SD bias (Paulhus, 2002). Paulhus's framework has been the subject of much attention and heated debate. Lanyon and Carle (2007) studied both the BIDR and the PDS with a population of injury claim, compensation and litigation cases (such as custody or criminal offences), and undergradu- ate students, and found the constructs overlapping but valid. Blake et al. (2006) argued that the impression-management dimensions of BIDR could be used for measuring SD bias. Lo" nnqvist, Paunonen, TuulioHenriksson, Lo"nnqvist, and Verkasalo (2007) did not find support for the division between conscious and unconscious bias; they argued that the two styles measure similar items to different extents but they are not distinctly sepa- rate. Pauls and Crost (2004) noted that the PDS does not add value to con- ventional personality measurement, as it is itself vulnerable to faking. Additionally, Dodaj (2012) found little support for the division between conscious and unconscious levels of SD bias. Roth and Herzberg (2007) claimed that the labels of selfdeception and impression management are misleading as both constructs measure deliberate faking, while Jowett (2008) found partial support for this distinction in coach-athlete relation- ships. The active research on SD bias constructs clearly demonstrates the topic's importance, yet it still fails to confirm whether the measurement scales provide a valid tool for bias quantification.

The concerns about the validity of the leading SD scales have posed serious problems for marketing research. Employing a 36-item Marlowe- Crowne scale as part of a survey instrument is generally not feasible. Yet the debated validity of shorter Marlowe-Crowne scales and the BIDR/ PDS raises doubts whether such items should be included in survey instruments. To explore the usefulness of the scales, Steenkamp et al. (2010) analyzed survey-based marketing studies from three marketing journals between 1968 and 2008, focusing on articles that tested for SD bias using measurement scales. They found that Marlowe-Crowne was used most often (26 times), while BIDR in either its complete form, or the impression-management construct only, was employed seven times. 
Steenkamp et al. did not report the total number of studies reviewed, but considering the long timespan they selected, it seems clear that only a fraction of academic marketing surveys employ SD scales as a solution for coping with desirability bias. However, they argue that the moralistic- egoistic division of Paulhus can act as a basis for successful desirability bias quantification.

Employing a meta-analysis, Beretvas et al. (2002) found three ways of applying results from SD scales to study findings. These were comparison of correlations between the scales and the focal instruments, deletion of responses from individuals with high desirability scores, and factor analy- sis between the desirability measures and the focal instrument. Later, however, Leite and Beretvas (2005) suggested that the lack of consensus on the structure of the SD construct makes such adjustments difficult or unreliable. Lee and Woodliffe (2010) further supported Leite and Beretvas by pointing out the weak conceptualization of SD dimensions. Based on the literature, support for treating SD as a construct that can be mea- sured through questions, similar to other psychological variables, seems divided. This may partly explain why Steenkamp et al. (2010) found so few studies attempting a quantitative measurement of SD in marketing research. Yet neglecting a quantitative assessment of SD bias reduces the value of marketing studies, even when nonquantitative methods of addres- sing desirability bias are employed. If the eradication of SD bias is assumed in a binary manner, as opposed to treating it as a quantifiable variable that fluctuates within a range, the magnitude of the bias cannot be estimated. The same is true for experimental designs that aim at disguising the intent of the research. A methodology that provides such an estimate could benefit the research of SD bias, particularly in situations where employing other methods for reducing the bias is difficult or unfeasible.

\section{Cynicism}

While SD has received much attention in behavioral literature, cynicism has been examined less, particularly in marketing studies. The difference between the two related attitudes, skepticism and cynicism, must be empha- sized: Cynicism is more a personality trait or a habitual disposition of viewing and thinking, while skepticism is a cognitive response to a certain type of input. While skepticism is short term, cynicism can be enduring (Anson, Dale Mann, \& Sherman, 1986). Furthermore, cynics doubt the motives behind any communications, as opposed to skeptics who focus on messages communicated only (Kanter \& Mirvis, 1986). Because of the more profound impact of cynicism on consumer surveys, this research con- centrates on cynicism rather than skepticism.

The two main fields of study regarding cynicism have been organiza- tional behavior and the police force. Several of the key scales for cynicism measurement have been developed while measuring the attitudes of the police force (Anson et al., 1986; Langworthy, 1987; Regoli, 1976), and more recent studies continue employing them in the same domain (Hickman, Piquero, \& Piquero, 2004; Sobol, 2010). Organizational cyni- cism was introduced as a concept by Dean, Brandes, and Dharwadkar (1998), though cynicism at the workplace had been investigated previously (Guastello, Rieke, Guastello, \& Billings, 1992; Kanter \& Mirvis, 1986). Recently, it has been introduced to the domain of academic researchers (Kalağan \& Aksu, 2010; Karadağ, Kilicoğlu, \& Yilmaz, 2014). In marketing literature, cynicism has gained new popularity for explaining the behavior of consumers, be it general reactions toward companies and advertising or consumer disappointment in a company (Chowdhury \& Fernando, 2013; 
Chylinski \& Chu, 2010; Odou \& de Pechpeyrou, 2011).

Based on the essence of cynicism as fundamental doubt of a relayed mes- sage, it is evident that cynicism affects how consumers perceive a marketing message. While skepticism might even benefit an advertiser, provided cor- rect adoption of the message to counter the skeptical attitude, cynicism is rarely advantageous (Boush, Kim, Kahle, \& Batra, 1993). However, a few brands that cynics truly trust can gain loyalty among this group (Helm, 2004). Chylinski and Chu (2010) synthesized studies on the effects of cynicism on consumer behavior toward a company and classified the result- ing behaviors as positive, neutral, or negative. The findings of their study further support this classification, but the analysis is restricted to scenarios where cynicism is prompted by negative company behavior. In a general consumer context, Helm (2004) suggested four categories of cynical behavior: disparaging, withdrawal, precaution, and retribution. Similar to disparaging cynical behavior is subversive cynicism, where verbal criticism is common but action avoided (Odou \& de Pechpeyrou, 2011). This type of cynicism further coincides with the "complaint" theme of Chylinski and Chu; consumers vent frustration or offer a company another chance through negative feedback without corresponding action. Cynicism toward marketing and advertising is easier to create than to eradicate (Chylinski \& Chu, 2010) but the resulting consumer behavior varies widely.

\section{Scales for Measuring Cynicism}

While the most widely used cynicism measurement scale, the Niederhoffer scale, is related to police work, Kanter and Mirvis (1986) took a business approach to cynicism measurement. Subsequently, Turner and Valentine (2001) developed a scale to measure sales personnel cynicism during inter- action with customers. In addition, Lee, Restori, and Katz (2010) provide cynicism subscales aimed at evaluating the general attitude of respondents toward corporations and big business. Such scales offer tools for addres- sing cynicism in CSR studies; a highly cynical consumer would likely doubt a marketing message because of mistrust in companies, but not necessarily act based on these doubts. Instead, cynicism may produce a similar but opposite effect to SD, where cynical and thus negative stated attitudes do not lead to corresponding actions. Chylinski and Chu (2010) emphasize that the impact of cynicism on consumers is under-researched, and this chapter will focus particularly on the impact of cynicism on stated rather than actual choices.

\section{CSR AND CONSUMER CHOICES}

Research has suggested that consumers are willing to pay more for pro- ducts from an ethical company; Creyer and Ross (1997) established this almost two decades ago. Fairtrade products have been a practical subject for studies. De Pelsmacker, Driesen, and Rayp (2005) noted consumers' willingness to pay (WTP) an average premium of $10 \%$ for Fairtrade products, though only $10 \%$ of respondents were willing to pay the existing premium of $27 \%$ at the time of the study. As Fairtrade grew to encompass products beyond coffee, the overall link between such product social orientation and consumer purchase intentions remained valid (Castaldo, Perrini, Misani, \& Tencati, 2009). Other ethical aspects, such as the use of child labor, employee working conditions, and environmental concerns, also play a role in consumer choices (Auger, Devinney, 
Louviere, \& Burke, 2008). These survey results are supported by the findings of Arnot, Boxall, and Cash (2006), who conducted a real-life choice experiment with Fairtrade coffee. They established that buyers of Fairtrade products were less price sensitive than the average, though an "optimal" premium for such products was not studied. While the existence of consumers willing to pay for ethical products seems evident, some doubt exists over the accuracy of such results (Auger \& Devinney, 2007).

\section{Social Desirability and Cynicism Biases in CSR Research}

In line with common practice in CSR behavior research, all the consumer studies mentioned in the previous section have employed questionnaire- based quantitative techniques to evaluate the connections between vari- ables, and such methods dominate consumer CSR research. Qualitative research in the field is rare (Peloza \& Shang, 2011), with a few authors (Bhattacharya \& Sen, 2004; Boulstridge \& Carrigan, 2000; O berseder, Schlegelmilch, \& Gruber, 2011; O berseder, Schlegelmilch, \& Murphy, 2013; Pomering \& Dolnicar, 2008; Webb \& Mohr, 1998) as notable exceptions interviewing consumers. Yet Peloza and Shang (2011), reviewing 164 con- sumer studies focused on CSR activities and outcomes, found that only 23 studies employed behavioral measures instead of attitudinal ones. They further noted that in these studies attitudinal biases were addressed in two main ways: using choice modeling methodology to reduce the impact of such biases in comparison to Likert-based methods (such as Auger et al., 2008) or conducting field experiments that present respondents with real choices instead of fictitious ones (e.g., Arnot et al., 2006). In more recent research, Moosmayer (2012) addressed the issue of SD by noting that "if WTP [willingness to pay] response and PE [product evaluation] response are both subject to a comparable SD bias, then their quotient is free of this effect" (p. 205), further supporting his conclusion by the use of a SD scale. Despite these efforts, it appears that the impact of SD on the results of quantitative surveys is often unaddressed when CSR and consumer deci- sions are studied, creating a potential gap between choices stated in the surveys and actions.

Mohr, Eroglu, and Scholder Ellen (1998) attempted to measure cynicism within a responsible marketing context, although they concluded that companies should concentrate on alleviating skepticism instead due to its non-permanent nature. CSR can alleviate skepticism (Mohr et al., 1998; Pirsch, Gupta, \& Grau, 2007; Skarmeas \& Leonidou, 2013) with more knowledge helping to generate positive attitudes (Webb \& Mohr, 1998). Cynicism, on the contrary, poses a severe problem to any attempts at creating positive consumer responses through CSR (Mohr et al., 1998; Vallaster, Lindgren, \& Maon, 2012) as it can dampen the favorable effects of CSR initiatives (Bhattacharya \& Sen, 2004). Although they did not differentiate between the two constructs, Pomering and Dolnicar (2008) noted the potential negative impact of skepticism and cynicism on CSR advertising. Cynicism can significantly weaken the effects of CSR activities and even overshadow potential benefits (Porter \& Kramer, 2006; Ricks, 2005; Vlachos, Tsamakos, Vrechopoulos, \& Avramidis, 2008). Unlike skepticism, dialogue with stakeholders may in fact breed cynicism (Crane \& Livesey, 2003), although cynicism does not foster mistrust of general product infor- mation (Boush et al., 1993). To avoid deeming responsible activities rejected by a highly cynical group as unappealing to consumers at large, we propose that cynicism is assigned a special role, similar to that of SD, when studying the effect of CSR on consumer choices. 
How important should these considerations be in survey design? Peloza and Shang (2011) employed the value model of Holbrook and suggested that ethical consumption stems from the search for four different elements, one of which is status or esteem. The existence of such an extrinsic and self-oriented motivation would directly lead to questions about a SD effect in survey answers, with respondents potentially attempting to make themselves appear to be "doing the right thing" without matching actions. On the other hand, lack of trust in a company can prompt cynicism that leads to ignorance, or subversively cynical reactions, toward responsibility- related questions in surveys, even if the same respondents act neutrally when actually making purchase decisions. In particular, early CSR consu- mer research occasionally suggested that claims of responsibility had a negative impact on purchase intentions (Boulstridge \& Carrigan, 2000; Mohr et al., 1998; Sen \& Bhattacharya, 2001), a reaction potentially prompted by cynicism. However, Vlachos et al. (2008), testing the links between strategic driven CSR and trust, repeat patronage intentions and recommendation intentions, found that only repeat patronage demon- strated a significant negative relationship with strategic CSR. Mohr et al. (1998) discovered that the level of skepticism toward a particular CSR action relates to cynicism, albeit mediated by negative sentiments. Thus cynicism toward a CSR message may not directly lead to a negative actual choice, as also noted in general marketing studies that focus on cynicism.

Traditional Likert-scale methods to measure purchase intention have been criticized for being subject to overestimation of positive intent (Auger \& Devinney, 2007). 0 berseder et al. (2011) also noted the gap between reported interest in CSR and its non-role in consumer purchase decisions, asking why consumers do not ultimately appear to care about responsibility. Several other authors have also questioned the difference between reported attitudes and actual behavior (Auger \& Devinney, 2007; Bhattacharya \& Sen, 2004; De Pelsmacker et al., 2005; Freestone \& McGoldrick, 2007; Valor, 2008). An extreme view was offered by Beckmann (2007), who proposed that when consumer reactions to CSR are studied, the chosen methodology will deter- mine the outcomes: Polls or surveys result in a positive link between CSR and product evaluation or purchase intent, while interviews find disinterest and more experimental designs produce inconclusive or complicated results. While this statement was based on anecdotal rather than empirical evidence, it highlights the importance of consumer psychology for validity of CSR research.

\section{Effect of Biases on Research Findings}

Fig. 1 synthesizes the proposed framework including SD and cynicism biases in quantitative, consumer-oriented CSR research. The usual dependent variables in such surveys are product/service choices made and WTP for responsible products, as depicted in the figure. However, psycho- logical aspects may cause the stated responses to deviate significantly from actions taken, creating an attitude-behavior gap, and thus these two out- comes have been separated in the framework. In addition, both CSR and non-CSR product attributes (such as functional aspects and brand) are considered. The effect of the non-CSR attributes are assumed to be the same on both stated and actual choices, with no psychological motivation to misrepresent answers; nonCSR attributes can have either positive, negative, or no effect on stated and actual choices. The effect of CSR attributes on stated and actual choices, on the other hand, can alternatively be direct, or created by SD or cynicism. 


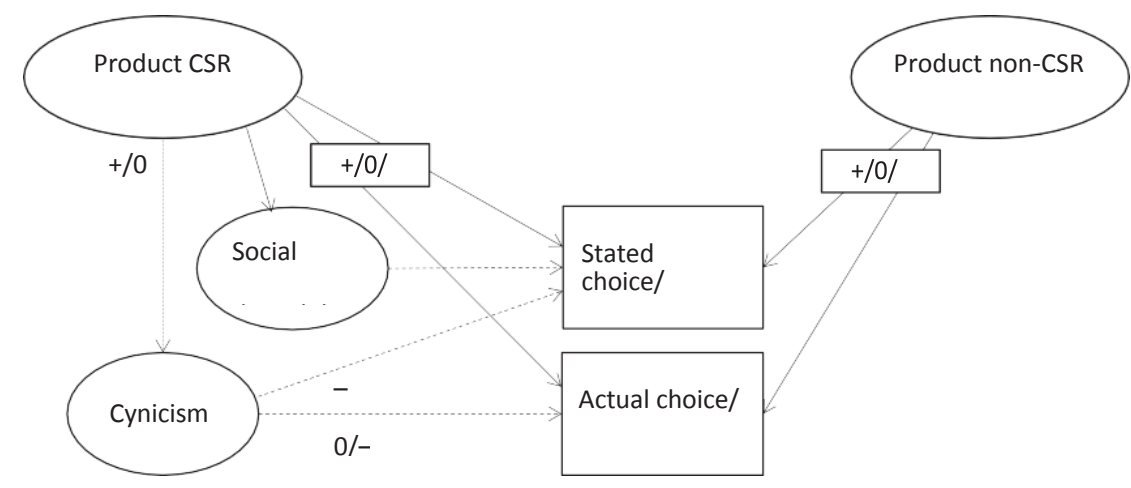

Fig. 1. The Asymmetric Effect of Social Desirability and Cynicism on Stated versus Actual Choices and Willingness to Pay (WTP).

CSR attributes may favorably impact the respondents' stated and actual choices and WTP, provided that the initiatives behind the attri- butes meet consumers' demand for responsibility. These attributes could also be simply ignored by consumers. Based on the notion of CSR as the ethically "right thing to do" (Bhattacharya \& Sen, 2004; Carrigan $\&$ Attalla, 2001), negative direct impact of CSR attributes is less likely. However, such effect cannot be ruled out, as seen in the mixed evidence on the CSP-CFP relationship and the potential of greenwashing (Crittenden, Crittenden, Ferrell, Ferrell, \& Pinney, 2010; Laufer, 2003). However, a person perceiving responsibility as a negative attribute may also be cynical. Should CSR attributes provoke SD bias in the respon- dents, their stated choices and WTP will favor a responsible product, with no corresponding effect on their choices and WTP in an actual purchase situation. Should cynicism be prompted by product CSR attributes, the result is likely a negative effect on stated choices, as a cynic would doubt such information and the organization providing it. Actual purchase choices and WTP may also be affected. However, as opposed to studies that prompt cynicism through a scenario of company misconduct, cyni- cism may be provoked by a responsibility emphasis in a survey. If a sub- sequent purchase situation lacks such strong CSR input, the cynic may well ignore its existence. Alternatively, the cynical consumer may only engage in subversive cynicism (Odou \& de Pechpeyrou, 2011) or express a complaint as a negative stated choice without an impact on actual choices (Chylinski \& $\mathrm{Chu}, 2010)$. As the diagram illustrates, stated and actual variables are affected through different mechanisms, resulting in a discon- nect between these two pairs of putatively matching variables. To ensure the validity of quantitative consumer CSR research, it is crucial to under- stand and quantify the roles SD and cynicism play in survey responses. This will lead to meaningful results when studying consumer views on responsible business.

\section{MODELING CONSUMER CHOICES}

Discrete choice modeling, first introduced by McFadden (1974), has become a standard technique for analyzing the choices of individuals in many fields including transportation, environmental economics, recrea- tional alternatives, and general product choices. It is 
based on the Random Utility Theory (RUT) (Thurstone, 1927) which divides the utility an indivi- dual draws from a product or service into two parts, the one observable by a researcher and the random component that only manifests itself to the individual:

\section{$\mathrm{Ut}{ }^{1 / 4} \mathrm{Vt} p \varepsilon t$}

where $U \mathrm{t}$ is the total utility, $V \mathrm{t}$ the utility observed by a researcher, and $\varepsilon \mathrm{t}$ the random component representing unobservable consumer preferences.

The term "random" in RUT does not imply random action on the part of the individual; instead, this part may seem random to an observer, while it is perfectly logical to an individual decision-maker due to personal pre- ferences and attitudes. Thus RUT does not contradict the fundamental idea in economics of individuals as rational utility maximizers; instead, it explains why sometimes choices made by an individual may seem irrational to an external observer.

Lancaster (1966) advanced consumer behavior theory by distinguishing between goods and the characteristics of those goods, and maintained that consumers gain utility from the characteristics rather than the goods them- selves. He transformed consumer behavior from a choice between goods to a choice between sets of characteristics, allowing for efficient analysis of substitution effect between goods. By considering changes of only one char- acteristic at a time, a basis for discrete choice modeling was provided; known product attributes explain the observable part of consumer utility, and the random part of the utility is modeled by employing a probability distribution to simulate it (McFadden, 1974). Discrete choice analysis assumes that consumers are rational, utility-maximizing individuals who make choices accordingly, but that an unobservable part of utility is a ran- dom variable modeled through a probability distribution. The observable part of utility is split among product attributes, each of which is assigned a coefficient signifying its relative importance compared to the other attri- butes, and socio-demographic characteristics are included as additional explanatory variables (Louviere, Hensher, \& Swait, 2000). The choice a respondent makes (either stated or revealed) is treated as the dependent variable in a logistic regression that estimates the effect of the attributes on consumer decision process (Ben-Akiva \& Lerman, 1985). Further analysis of these estimators can include calculations of consumer WTP for various attributes, or prediction of market shares, among others.

\section{Perceptions and Attitudes in Choice Modeling}

In the standard discrete choice model, the resulting estimators represent the importance of the attribute in question combined with attitudinal aspects that are not explained through socio-demographic variables. It is impossi- ble to break down the combination into its components, and thus SD and cynicism will both complicate the interpretation of the coefficients. McFadden (1986) therefore suggested the inclusion of latent variables as part of the framework. He emphasized perceptions and attitudes as critical inputs to modeling choices, and proposed latent variables such as cost- consciousness as additional inputs to advance analysis of the choices consumers make. According to Kahneman, Ritov, and Schkade (1999), "statements of WTP are better viewed as expressions of attitudes than as indications of economic preferences" (p. 204), supporting the notion that to understand choices thoroughly, attitudinal and perceptional indicators belong to a choice modeling 
framework. Several academics took early interest in the potential of psychometric data and the addition of latent variables in their models (Ben-Akiva \& Boccara, 1995; Ben-Akiva et al., 1999; Bö rsch-Supan, McFadden, \& Schnabel, 1996; Gopinath, 1995; McFadden, 1999; Morikawa \& Sasaki, 1998). The potential of attitudinal variables to explain choices justifies the appeal such approaches have over the traditional choice modeling framework.

\section{Hybrid Choice Models}

Walker (2001) and Ben-Akiva and Walker (2002) formulated the frame- work for implementing latent variables in choice models. This model for- malizes the connection between traditional inputs and outputs of a choice model (product attributes, sociodemographic characteristics) and attitudes and perceptions included as latent variables. Their subsequent generalized choice model framework (Walker \& Ben-Akiva, 2002), later also dubbed a hybrid choice model (Bolduc, Ben-Akiva, Walker, \& Michaud, 2005), extended choice modeling theory to encompass psychological aspects in full. In line with human behavior, the framework includes these aspects as latent variables that contribute to the total utility leading to a choice (Walker, 2001). In a hybrid choice model, latent variables explain answers to related indicator questions, as opposed to indicator questions measuring a latent construct, while they simultaneously impact the utility of a choice. The indicator questions for latent variables included in a survey instrument do not measure that construct, reversing the traditional relationship between survey questions and psychological variables.

Early practical examples of this technique were offered by Ashok, Dillon, and Yuan (2002) and Ben-Akiva and Walker (2002). Ashok et al. included the latent variables of "satisfaction" and "barriers to change" in their model, while Ben-Akiva and Walker employed latent variables such as "comfort," "convenience," and "satisfaction" in their case studies. However, computational restrictions slowed down the application of hybrid choice models in practice (Ben-Akiva, McFadden, Train, \& Walker, 2002), and full application of the technique has only started recently. Since computing power caught up with theory, hybrid analysis has become more common (Hensher, Rose, \& Beck, 2012), with a multitude of examples where latent variables include flexibility, safety, hedonism, support for rele- vant policies, perception of potential problems, propensity to travel, and environmental attitudes (Abou-Zeid, Ben-Akiva, Bierlaire, Choudhury, \& Hess, 2011; Alvarez-Daziano, 2010; Alvarez-Daziano \& Bolduc, 2009; Bolduc \& Alvarez-Daziano, 2010; Daly, Hess, Patruni, Potoglou, \& Rohr, 2011; Dannewald, Paulssen, Temme, \& Walker, 2009; Hess \& Beharry- Borg, 2011; Hoyos \& Mariel, 2013; Maquilon \& Alvarez, 2012; Mariel, Meyerhoff, \& Hess, 2013; Paix, Bierlaire, Cherchi, \& Monzon, 2011; Temme, Paulssen, \& Dannewald, 2008; Tudela, Nurul Habib, Carrasco, \& Osman, 2011). These studies all employed latent variables based on psycho- logical and sociodemographic indicators as explanatory variables to uti- lity. However, only four of these studies used indicator questions based on established psychometric scales (Daly et al., 2011; Hoyos \& Mariel, 2013; Maquilon \& Alvarez, 2012; Tudela et al., 2011); the rest developed their own indicator questions for the latent variables in the studies.

\section{Modeling Ethical Choices}

While choice modeling and related techniques have been widely employed in many 
fields of marketing research, ethical consumption and CSR in particular have remained largely on the sidelines. De Pelsmacker et al. (2005) employed conjoint analysis to estimate the WTP a premium for Fairtrade coffee. Multiple examples of choice studies focusing on environ- mental attitudes exist, but to our knowledge there is only one major research thread combining choice modeling with ethical purchase behavior, despite Aran a and Leo'n (2013) demonstrating validity of choice modeling in CSR research. Auger, Burke, Devinney, and Louviere (2003) established support for anecdotal evidence related to choices favoring ethical brands such as The Body Shop. Auger, Devinney, and Louviere (2006) studied consumer behavior related to ethical and social aspects using Best-Worst scaling, further combining stated preferences with actual purchase behavior. Auger et al. (2008) discovered that consumers will not trade pro- duct functionality for ethical considerations; yet segments of consumers who prefer ethical alternatives when product performance is not jeopar- dized exist. On the other hand, Lusk and Briggeman (2009) discovered that fair business practices toward producers were of low importance to consumers selecting food products. In a wide-ranging study exploring the influ- ence of social attributes on purchase intentions, Auger, Devinney, Louviere, and Burke (2010) concluded that social attributes are important both in high- and low-involvement products and they affect choice, even when intangible aspects such as brands are included in the choice scenario. The limited application of choice modeling within the field has concentrated mostly on ethical product attributes; such attributes existed on the market at the time the studies were conducted. However, no research has combined the use of latent variables to explain how strongly attitudes con- tribute to the utility defining a choice.

\section{QUANTIFYING ATTITUDINAL BIASES IN CSR RESEARCH}

SD and cynicism can seriously distort the validity of consumer-oriented CSR research by creating a potential disconnect between stated outcomes of a study and real actions. Even when respondents are not prone to such traits, current studies do not allow for confirming the lack of bias in results. The majority of CSR studies do not address questions related to SD, and cynicism has so far been paid little attention in the field. The challenge of measuring these aspects in marketing research likely explains the former, as the validity of instruments and scales intended to quantify desirability bias is not universally accepted. Cynicism as a concept is rarely discussed.

Employing hybrid choice modeling, we propose a framework that allows estimating the magnitude of these attitudinal biases in consumer survey results related to responsibility. The model aims to reduce the gap between stated and actual choices in CSR consumer studies by integrating SD and cynicism biases to analysis of survey results. Furthermore, through quanti- fying SD and cynicism in a novel manner, it is hoped that the proposed modeling technique will open the door to new insights into the effects these two attitudes have on consumers.

\section{Attitudinal Biases in a Choice Model Framework}

The hybrid choice model in Fig. 2 demonstrates how common biases in CSR consumer research can be extracted and addressed. Following standard practice in choice modeling, rectangles signify measured variables while latent variables are presented as ellipses. 


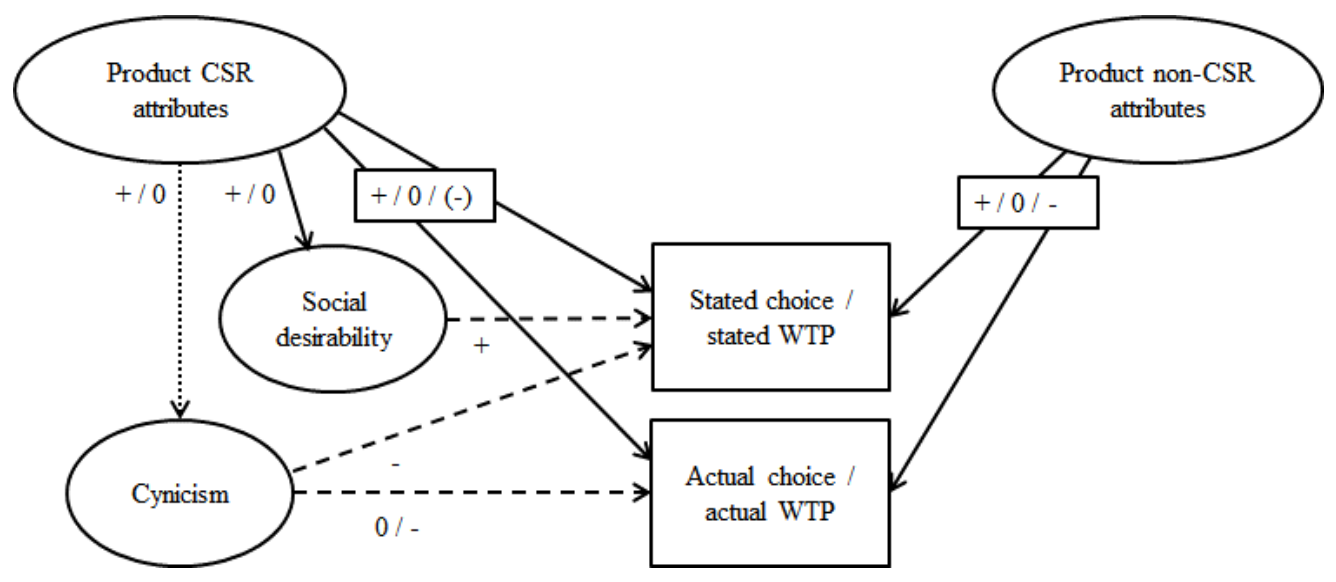

Fig. 2. Hybrid Choice Model Incorporating Latent Variables of Social Desirability and Cynicism in CSR Consumer Research.

The arrows mark the direction of causation between variables; solid lines represent structural equations (a link that governs decision-making) and dotted lines indicate measurement equations (manifestations of an unobservable variable). Conceptually, the model presents two new latent variables, Consumer Social Desirability (CSD) and Consumer Social Cynicism (CSC). These variables, measured by indicator questions from the respective fields, contribute in explaining the heterogeneity in preferences between individuals by linking it with SD and cynicism, two factors often present when responsibility is surveyed. Instead of all the utility being associated with product CSR and non-CSR attributes and respondents' socio-demographic characteristics, CSD and CSC will account for part of it. The resulting estimators for importance of product CSR attributes will thus be controlled for these biases. Unlike earlier attempts to control for such biases in quantitative CSR research, the hybrid model will not impose a fixed relationship between the latent variables and the indicators, and the impact may be restricted to only some of the CSR attributes in the survey.

The left part of Fig. 2 presents the traditional inputs of a choice model; product or service attributes with attribute levels that differ in each choice scenario and sociodemographic characteristics. When consumer CSR choices are surveyed, the attributes include aspects related to responsibility. These are presented in the choice instrument and contribute to the utility a consumer draws from an alternative. Total utility (an unobservable vari- able), further explained by socio-demographic factors (such as gender, income, or education), manifests itself as the consumer choice in a survey (stated preference) or in real life (revealed preference). In the traditional choice model, the utility is assumed to be comparable in both situations. However, when choices related to responsibility are studied, we propose that CSD and CSC impact the total utility differently when stated and revealed choices are considered, as depicted earlier in Fig. 1: with stated choices, the two variables may decrease or increase the utility of a choice, while revealed choices are free of such biases. CSD and CSC are included in the stated choice model as latent variables that impact total utility; their real values cannot be observed but indications of such biases are provided by questions included in the survey 
instrument. Should indicator questions measuring SD and cynicism indicate biases, all the choices of the respon- dents in the survey are assumed to be equally affected by CSD and CSC. These two latent variables are included in the model via structural equa- tions explaining answers to indicator questions. Simultaneously, they explain the amount of utility that originates from indicating the selection of an alternative; this differs from the attributes and socio-demographic characteristics that explain utility from actually selecting the alternative. Solving the choice model with CSC and CSD and explaining a portion of the utility leading to a choice will reduce the impact of attributes and sociodemographic characteristics when biases exist, thus controlling their estima- tors for such biases. In a case where a respondent indicates little or no tendency for the biases, the CSC and CSD remain insignificant and have limited or no impact on total utility. Thus the importance of CSR product attributes provided by a stated preference study will better match with actual choices, enhancing the validity of consumer-oriented CSR surveys.

There are several practical alternatives to control the results for the latent features, depending on the strength of the biases. High levels of CSD and CSC biases indicate wide attitude-behavior gap. The biases could dom- inate the overall stated choice; this equals to a situation where respondents draw utility from stating a responsible choice or rejecting one without further consideration of the other attributes presented in the products. In such a case, the two latent variables may directly explain part of the resulting utility as discussed earlier. CSD and CSC will be incorporated as independent variables in the model, and the estimators for these two become significant to choice. The impact of product attributes will decline com- pared to a model without the latent variables and the estimator coefficients for importance of CSC/CSD variables effectively become measures of the attitude-behavior gap created by each bias. However, a more likely case is a situation where respondents demonstrate a biased reaction toward one or more of the CSR attributes in the choice scenario; some of these reactions result from CSD while others are caused by CSC. In this situation, the bias on choices can be modeled by including additional CSD/CSC coefficients only for the attributes affected; this equals stating that only certain CSR attributes provoke SD or cynicism biases. The estimator for the importance of a CSR attribute will be divided between the actual impact of the attribute on choice and the bias that the attribute provokes. In this case, the former figure approximates the effect of the attribute on actual behavior and the latter signifies the attitude-behavior gap. Thus an empirical study offering respondents choices linked with CSR while collecting SD and cynicism data will be the next step required in developing the model further and understanding how the two biases contribute to an attitude-behavior gap.

\section{Limitations of the Framework}

The hybrid model presented in Fig. 2 is limited to situations where CSR is expressed through product or service attributes, as the aim is to focus on reducing the gap between stated and actual choices in surveys. However, the utility from CSR could also result from personal characteristics of the respondent, and additional latent variables could be employed to further dissect the utility from a choice. As an example, consumer personal ethics might be added as a third latent variable to explain utility created from "doing the right thing," particularly in conjunction with different product scenarios and varying levels of CSR (Strahilevitz, 1999). Schro" der and McEachern (2005) argue that choices are influenced by the ethical beliefs of a decision-maker, and green values generally affect 
consumption behavior (Haws, Winterich, \& Naylor, 2014; Lin \& Huang, 2012). On the other hand, Auger and Devinney (2007) discovered no clear link between respon- dents' ethical values and their WTP for such product aspects. The impact of consumers' ethical beliefs could, however, interact with the level of none- thical product attributes (Folkes \& Kamins, 1999) and such an interaction could also be tested with the hybrid model proposed. Sudbury Riley, Kohlbacher, and Hofmeister (2012) demonstrated that sociodemographic characteristics cannot explain ethical beliefs of an individual, and thus the inclusion of such a latent variable would likely not create multicollinearity with the sociodemographic variables in the model, supporting the feasibil- ity of such an addition. The HCM framework proposed here could thus provide a new approach to this contested area.

Several scales for measuring SD bias and cynicism exist, but results on their validity are mixed. Before the model can be operationalized, a scale with the best fit to purpose must be defined for both variables. Furthermore, the decision to favor responsibility could be attributed to other latent features, such as a specific personal situation or the reference groups of the respondent. The model proposed here does not address such situations, but by identifying and including the relevant latent variables it could be generalized to cover a wider range of CSR choice situations. While the framework is open to many adaptations, questions of multicollinearity between the various explanatory variables and mathematical identification of the model could become limiting factors for increasing complexity.

\section{CONCLUSIONS}

This chapter aims to address several issues in current CSR research and to contribute to improved validity of responsibility surveys. First, it highlights the gap created by SD bias in consumer-oriented CSR research, a topic underemphasized in literature. Quantifying an estimator for this bias will help to evaluate the real effect of responsibility on consumer choices and to reduce the gap between stated and actual choices, as surveys of the pro- posed type can better estimate the real actions respondents are willing to take based on CSR. The model could also contribute to other social science studies where disagreement over quantification of SD bias has complicated research. Similarly, the model adds the notion of cynicism as a persistent personality trait that differs from skepticism commonly addressed in the field. It highlights the gap, similar but opposite to SD bias that cynicism may create between stated and actual choices.

The proposed framework further advances the use of hybrid choice modeling to a new field of application; while attitudinal variables have been occasionally employed in such models, this proposition harnesses latent variables to address specific issues related to survey validity, as opposed to general improvement of model fit. For CSR research, this can improve the way biases are controlled for and quantified. The approach also avoids problems encountered in development of constructs for SD bias measurement and its application in earlier research. In a latent variable model, the measurement equations treat the answers to questions as indicators of a latent feature, as opposed to employing them as structural cause-and-effect measurements of a specific construct. Thus the existing controversy over the validity of these scales can be averted. The difficulties in measurement of SD bias may have been an important contributing fac- tor to its relatively rare inclusion in marketing research (Steenkamp et al., 2010). Thus a novel way of measuring biases that potentially create differ- ences between survey results and real 
actions can improve the validity of CSR survey results through decreasing the gap between stated and real actions, and enhance understanding of which responsible product attributes impact consumers' actual choices. This in turn will increase the value of such research for practitioners, as the common problem of survey results deviating from real actions can be circumvented.

\section{REFERENCES}

Abou-Zeid, M., Ben-Akiva, M., Bierlaire, M., Choudhury, C., \& Hess, S. (2011). Attitudes and value of time heterogeneity. In 90th annual meeting of the transportation research board. Washington, DC.

Accenture, United Nations Global Compact, \& Havas Media. (2014, June). The consumer study: From marketing to mattering. Retrieved from http://www.havasmedia.co.uk/ wp-content/uploads/Havas_Accenture-Consumer-Study_2014-low-res.pdf. Accessed on August 10, 2014.

Alvarez-Daziano, R. (2010). A Bayesian approach to hybrid choice models. PhD dissertation, Universite' Laval Quebec.

Alvarez-Daziano, R., \& Bolduc, D. (2009). Canadian consumers' perceptual and attitudinal responses toward green automobile technologies: An application of hybrid choice mod- els. In 2009 EAERE-FEEM-VIU European Summer School in Resources and Environmental Economics: Economics, Transport and Environment. Venice.

Andrews, P., \& Meyer, R. G. (2003). Marlowe-Crowne social desirability scale and short form C: Forensic norms. Journal of Clinical Psychology, 59, 483-492. doi:10.1002/jclp.10136

Anson, R. H., Dale Mann, J., \& Sherman, D. (1986). Niederhoffer's cynicism scale: Reliability and beyond. Journal of Criminal Justice, 14, 295-305. doi:10.1016/00472352(86) 90123-6

Arañ a, J. E., \& Leo’ n, C. J. (2013). Dynamic hypothetical bias in discrete choice experiments: Evidence from measuring the impact of corporate social responsibility on consumers demand. Ecological Economics, 87, 53-61. doi:10.1016/j.ecolecon.2012.12.005

Arnold, H. J., \& Feldman, D. C. (1981). Social desirability response bias in self-report choice situations. Academy of Management Journal, 24, 377-385. doi:10.2307/255848

Arnot, C., Boxall, P. C., \& Cash, S. B. (2006). Do ethical consumers care about price? A revealed preference analysis of Fair Trade coffee purchases. Revue Canadienne d'Agroeconomie [Canadian Journal of Agricultural Economics], 54, 555-565. doi:10.1111/ j.1744-7976.2006.00066.x

Ashok, K., Dillon, W. R., \& Yuan, S. (2002). Extending discrete choice models to incorporate attitudinal and other latent variables. Journal of Marketing Research, 39, 31-46. doi:10.1509/jmkr.39.1.31.18937

Auger, P., Burke, P., Devinney, T., \& Louviere, J. (2003). What will consumers pay for social product features? Journal of Business Ethics, 42, 281-304. doi:10.1023/ A: 1022212816261

Auger, P., \& Devinney, T. M. (2007). Do what consumers say matter? The misalignment of preferences with unconstrained ethical intentions. Journal of Business Ethics, 76, 361383. doi:10.1007/s10551-006-9287-y 
Auger, P., Devinney, T. M., \& Louviere, J. J. (2006). Using best-worst scaling methodology to investigate consumer ethical beliefs across countries. Journal of Business Ethics, 70, 299-326. doi:10.1007/s10551-006-9112-7

Auger, P., Devinney, T. M., Louviere, J. J., \& Burke, P. F. (2008). Do social product features have value to consumers? International Journal of Research in Marketing, 25, 183-191. doi:10.1016/j.ijresmar.2008.03.005

Auger, P., Devinney, T. M., Louviere, J. J., \& Burke, P. F. (2010). The importance of social product attributes in consumer purchasing decisions: A multi-country comparative study. International Business Review, 19, 140-159. doi:10.1016/j.ibusrev.2009.10.002

Barger, S. D. (2002). The Marlowe-Crowne affair: Short forms, psychometric structure, and social desirability. Journal of Personality Assessment, 79, 286-305. doi:10.1207/ S15327752JPA7902_11

Barnett, M. L., \& Salomon, R. M. (2012). Does it pay to be really good? Addressing the shape of the relationship between social and financial performance. Strategic Management Journal, 33, 1304-1320. doi:10.1002/smj.1980

Beckmann, S. C. (2007). Consumers and corporate social responsibility: Matching the unmatchable? Australasian Marketing Journal, 15, 27-36. doi:10.1016/S1441-3582(07) 70026-5

Ben-Akiva, M., \& Boccara, B. (1995). Discrete choice models with latent choice sets. International Journal of Research in Marketing, 12, 9-24. doi:10.1016/0167-8116(95) 00002-J

Ben-Akiva, M., McFadden, D., Garling, T., Gopinath, D., Walker, J., Bolduc, D., Rao, V. (1999). Extended framework for modeling choice behavior. Marketing Letters, 3, 187203. doi:10.1023/A:1008046730291

Ben-Akiva, M., McFadden, D., Train, K., \& Walker, J. (2002). Hybrid choice models: Progress and challenges. Marketing Letters, 13, 163-175. doi:10.1023/A:1020254 301302

Ben-Akiva, M., \& Walker, J. (2002). Integration of choice and latent variable models. In H. Mahmassani (Ed.), Perpetual motion: Travel behaviour research opportunities and application challenges (pp. 431-470). Amsterdam: Elsevier Science.

Ben-Akiva, M. E., \& Lerman, S. R. (1985). Discrete choice analysis. Cambridge, MA: The MIT Press.

Beretvas, S. N., Meyers, J. L., \& Leite, W. L. (2002). A reliability generalization study of the Marlowe-Crowne social desirability scale. Educational and Psychological Measurement, 62, 570-589. doi:10.1177/0013164402062004003

Bhattacharya, C. B., \& Sen, S. (2003). Consumer-company identification: A framework for understanding consumers' relationships with companies. Journal of Marketing, 67, 76-88. doi:10.1509/jmkg.67.2.76.18609

Bhattacharya, C. B., \& Sen, S. (2004). Doing better at doing good: When, why, and how con- sumers respond to corporate social initiatives. California Management Review, 47, 9-25.

Blake, B. F., Valdiserri, J., Neuendorf, K. A., \& Nemeth, J. (2006). Validity of the SDS17 measure of social desirability in the American context. Personality and Individual Differences, 40, 1625-1636. doi:10.1016/j.paid.2005.12.007

Bolduc, D., \& Alvarez-Daziano, R. (2010). On estimation of hybrid choice models. In S. Hess \& A. Daly (Eds.), Choice modelling: The state-of-the-art and the state-of-practice. 
Proceedings from the inaugural international choice modelling conference (pp. 259-287). Bingley, UK: Emerald Group Publishing Limited.

Bolduc, D., Ben-Akiva, M. E., Walker, J., \& Michaud, A. (2005). Hybrid choice models with logit kernel: Applicability to large scale models. In M. E. H. Lee-Gosselin \& S. T. Doherty (Eds.), Integrated land-use and transportation models: Behavioural foundations (pp. 275-302). Oxford: Elsevier.

Börsch-Supan, A., McFadden, D. L., \& Schnabel, R. (1996). Living arrangements: Health and wealth effects. In D. A. Wise (Ed.), Advances in the economics of aging (pp. 193216). Chicago, IL: University of Chicago Press.

Boulstridge, E., \& Carrigan, M. (2000). Do consumers really care about corporate responsibil- ity? Highlighting the attitude - Behaviour gap. Journal of Communication Management, 4, 355-368. doi:10.1108/eb023532

Boush, D., Kim, C., Kahle, L. R., \& Batra, R. (1993). Cynicism and conformity as correlates of trust in product information sources. Journal of Current Issues and Research in Advertising, 15, 71-79. doi:10.1080/10641734.1993.10505004

Carrigan, M., \& Attalla, A. (2001). The myth of the ethical consumer - Do ethics matter in purchase behaviour? Journal of Consumer Marketing, 18, 560-577.

Carroll, A. B., \& Shabana, K. M. (2010). The business case for corporate social responsibility: A review of concepts, research and practice. International Journal of Management Reviews, 12, 85-105. doi:10.1111/j.1468-2370.2009.00275.x

Castaldo, S., Perrini, F., Misani, N., \& Tencati, A. (2009). The missing link between corporate social responsibility and consumer trust: The case of Fair Trade products. Journal of Business Ethics, 84, 1-15. doi:10.1007/s10551-008-9669-4

Chowdhury, R. M. M. I., \& Fernando, M. (2013). The relationships of empathy, moral iden- tity and cynicism with consumers' ethical beliefs: The mediating role of moral disen- gagement. Journal of Business Ethics, 124, 677-694. doi:10.1007/s10551-0131896-7

Chylinski, M., \& Chu, A. (2010). Consumer cynicism: Antecedents and consequences. European Journal of Marketing, 44, 796-837. doi:10.1108/03090561011032720

Crane, A., \& Livesey, S. (2003). Are you talking to me? Stakeholder communication and the risks and rewards of dialogue. In J. Andriof, S. Waddock, B. Husted, \& S. S. Rahman (Eds.), Unfolding stakeholder thinking: Relationships, communication, reporting and performance (pp. 39-52). Sheffield: Greenleaf.

Creyer, E. H., \& Ross, W. T. (1997). The influence of firm behavior on purchase intention: Do consumers really care about business ethics? Journal of Consumer Marketing, 14, 421-432. doi:10.1108/07363769710185999

Crittenden, V. L., Crittenden, W. F., Ferrell, L. K., Ferrell, O. C., \& Pinney, C. C. (2010). Market-oriented sustainability: A conceptual framework and propositions. Journal of the Academy of Marketing Science, 39, 71-85. doi:10.1007/s11747-010-0217-2

Crowne, D. P., \& Marlowe, D. (1960). A new scale of social desirability independent of psychopathology. Journal of Consulting Psychology, 24, 349-354.

Daly, A., Hess, S., Patruni, B., Potoglou, D., \& Rohr, C. (2011). Using ordered attitudinal indicators in a latent variable choice model: A study of the impact of security on rail travel behaviour. Transportation, 39, 267-297. doi:10.1007/s11116-011-9351-z

Dannewald, T., Paulssen, M., Temme, D., \& Walker, J. (2009). Hybrid choice models estimation using canned SEM software. In Flexible marketing in an unpredictable world. Proceedings of the 36th EMAC conference. Reykjavik: European Marketing 
Academy.

De Jong, M. G., Pieters, R., \& Fox, J.-P. (2010). Reducing social desirability bias through item randomized response: An application to measure underreported desires. Journal of Marketing Research, 47, 14-27. doi:10.1509/jmkr.47.1.14

De Pelsmacker, P., Driesen, L., \& Rayp, G. (2005). Do consumers care about ethics? Willingness to pay for Fair Trade coffee. Journal of Consumer Affairs, 39, 363-385. doi:10.1111/j.1745-6606.2005.00019.x

Dean, J. W., Brandes, P., \& Dharwadkar, R. (1998). Organizational cynicism. Academy of Management Review, 23, 341-352. doi:10.5465/AMR.1998.533230

Dodaj, A. (2012). Social desirability and self-reports: Testing a content and response-style model of socially desirable responding. Europe's Journal of Psychology, 8, 651-666. doi:10.5964/ejop.v8i4.462

Edelman. (2012, April 25). Goodpurpose 2012. Retrieved from http://purpose.edelman.com/slides/introducing-goodpurpose-2012/. Accessed on May 8, 2013.

Fernandes, M. F., \& Randall, D. M. (1992). The nature of social desirability response effects in ethics research. Business Ethics Quarterly, 2, 183. doi:10.2307/3857570

Fisher, R., \& Tellis, G. (1998). Removing social desirability bias with indirect questioning: Is the cure worse than the disease. Advances in Consumer Research, 25, 563-567.

Fisher, R. J. (1993). Social desirability bias and the validity of indirect questioning. Journal of Consumer Research, 20, 303-315.

Folkes, V., \& Kamins, M. (1999). Effects of information about firms' ethical and unethical actions on consumers' attitudes. Journal of Consumer Psychology, 8, 243259. doi:10.1207/s15327663jcp0803_03

Freestone, O. M., \& McGoldrick, P. J. (2007). Motivations of the ethical consumer. Journal of Business Ethics, 79, 445-467. doi:10.1007/s10551-007-9409-1

Gopinath, D. (1995). Modeling heterogeneity in discrete choice processes: Application to travel demand. Ph.D. dissertation, Massachusetts Institute of Technology.

Gordon, R. (1987). Social desirability bias: A demonstration and technique for its reduction.

Teaching of Psychology, 14, 40-42. doi:10.1207/s15328023top1401_11

Greenberg, B., \& Weiss, P. (2012). Validation of a short form of the Marlowe-Crowne for use with law enforcement personnel. Journal of Police and Criminal Psychology, 27, 123128. doi:10.1007/s11896-012-9100-z

Groza, M. D., Pronschinske, M. R., \& Walker, M. (2011). Perceived organizational motives and consumer responses to proactive and reactive CSR. Journal of Business Ethics, 102, 639-652. doi:10.1007/s10551-011-0834-9

Guastello, S. J., Rieke, M. L., Guastello, D. D., \& Billings, S. W. (1992). A study of cynicism, personality, and work values. The Journal of Psychology, 126, 37-48. doi:10.1080/ 00223980.1992.10543339

Haws, K. L., Winterich, K. P., \& Naylor, R. W. (2014). Seeing the world through GREEN- tinted glasses: Green consumption values and responses to environmentally friendly products. Journal of Consumer Psychology, 24, 336-354. doi:10.1016/j.jcps.2013.11.002

Helm, A. (2004). Cynics and skeptics: Consumer dispositional trust. In B. E. Kahn \& M. F. Luce (Eds.), Advances in Consumer Research (pp. 345-351). Valdosta, GA: Association for Consumer Research. 
Hensher, D. A., Rose, J. M., \& Beck, M. J. (2012). Are there specific design elements of choice experiments and types of people that influence choice response certainty? Journal of Choice Modelling, 5, 77-97. doi:10.1016/S1755-5345(13)70049-6

Hess, S., \& Beharry-Borg, N. (2011). Accounting for latent attitudes in willingness-to-pay stu- dies: The case of coastal water quality improvements in Tobago. Environmental and Resource Economics, 52, 109-131. doi:10.1007/s10640-011-9522-6

Hickman, M. J., Piquero, N. L., \& Piquero, A. R. (2004). The validity of Niederhoffer's cyni- cism scale. Journal of Criminal Justice, 32, 1-13. doi:10.1016/j.jcrimjus.2003.10.001

Hoyos, D., \& Mariel, P. (2013). Environmental value orientations in discrete choice experi- ments: A latent variables approach. In International choice modelling conference 2013. Sydney.

Johnson, T. P., Fendrich, M., \& Mackesy-Amiti, M. E. (2012). An evaluation of the validity of the Crowne-Marlowe need for approval scale. Quality \& Quantity, 46, 1883-1896. doi:10.1007/s11135-011-9563-5

Jowett, S. (2008). The measurement of socially desirable responding in two-person relationships: The coach-athlete relationship. Journal of Clinical Sport Psychology, 2, 108-126.

Kahneman, D., Ritov, I., \& Schkade, D. (1999). Economic preferences or attitude expressions?: An analysis of dollar responses to public issues. Journal of Risk and Uncertainty, 19, 203-235. doi:10.1007/978-94-017-1406-8_8

Kalag an, G., \& Aksu, M. B. (2010). Organizational cynicism of the research assistants: A case of Akdeniz University. Procedia - Social and Behavioral Sciences, 2, 4820-4825. doi:10.1016/j.sbspro.2010.03.777

Kanter, D. L., \& Mirvis, P. H. (1986). The cynical Americans. San Francisco, CA: JosseyBass. Karadag , E., Kilic, og lu, G., \& Yilmaz, D. (2014). Organizational cynicism, school culture, and academic achievement: The study of structural equation modeling. Educational Sciences: Theory \& Practice, 14, 102-114. doi:10.12738/estp.2014.1.1640

Kemper, J., Schilke, O., Reimann, M., Wang, X., \& Brettel, M. (2013). Competitionmotivated corporate social responsibility. Journal of Business Research, 66, 19541963. doi:10.1016/j.jbusres.2013.02.018

Koschate-Fischer, N., Stefan, I. V., \& Hoyer, W. D. (2012). Willingness to pay for causerelated marketing: The impact of donation amount and moderating effects. Journal of Marketing Research, 49, 910-927. doi:10.1509/jmr.10.0511

Kuncel, N. R., \& Tellegen, A. (2009). A conceptual and empirical reexamination of the measurement of the social desirability of items: Implications for detecting desirable response style and scale development. Personnel Psychology, 62, 201-228. doi:10.1111/j.17446570.2009.01136.x

Lancaster, K. (1966). A new approach to consumer theory. The Journal of Political Economy, 74, 132-157. doi:10.2307/1828835

Langworthy, R. H. (1987). Police cynicism: What we know from the Niederhoffer scale. Journal of Criminal Justice, 15, 17-35. doi:10.1016/0047-2352(87)90075-4

Lanyon, R. I., \& Carle, A. C. (2007). Internal and external validity of scores on the balanced inventory of desirable responding and the Paulhus deception scales. Educational and Psychological Measurement, 67, 859-876. doi:10.1177/0013164406299104

Laufer, W. S. (2003). Social accountability and corporate greenwashing. Journal of Business Ethics, 43, 253-261. doi:10.1023/A:1022962719299 
Lee, H. B., Restori, A. F., \& Katz, G. S. (2010). A factor structure and psychometric evalua- tion of the hunter cynicism scale. Psychology Journal, 7, 121-127.

Lee, Z., \& Woodliffe, L. (2010). Donor misreporting: Conceptualizing social desirability bias in giving surveys. VOLUNTAS: International Journal of Voluntary and Nonprofit Organizations, 21, 569-587. doi:10.1007/s11266-010-9153-5

Leite, W. L., \& Beretvas, S. N. (2005). Validation of scores on the Marlowe-Crowne social desirability scale and the balanced inventory of desirable responding. Educational and Psychological Measurement, 65, 140-154. doi:10.1177/0013164404267285

Lin, P. C., \& Huang, Y. H. (2012). The influence factors on choice behavior regarding green products based on the theory of consumption values. Journal of Cleaner Production, 22, 11-18. doi:10.1016/j.jclepro.2011.10.002

Lo" nnqvist, J.-E., Paunonen, S., Tuulio-Henriksson, A., Lo" nnqvist, J., \& Verkasalo, M. (2007). Substance and style in socially desirable responding. Journal of Personality, 75, 291-322. doi:10.1111/j.1467-6494.2006.00440.x

Loo, R., \& Thorpe, K. (2000). Confirmatory factor analyses of the full and short versions of the Marlowe-Crowne social desirability scale. The Journal of Social Psychology, 140, 628-635. doi:10.1080/00224540009600503

Louviere, J. J., Hensher, D. A., \& Swait, J. (2000). Stated choice methods: Analysis and applica-tions. Cambridge: Cambridge University Press.

Lusk, J. L., \& Briggeman, B. C. (2009). Food values. American Journal of Agricultural Economics, 91(1), 184-196. doi:10.1111/j.1467-8276.2008.01175.x

Maquilon, J. C., \& Alvarez, G. J. (2012). Inclusion of the latent personality variable in multi- nomial logit models using the 16PF psychometric test. Dyna, 79, 62-70.

Margolis, J. D., Elfenbein, H. A., \& Walsh, J. P. (2009). Does it pay to be good ... and does it matter? A meta-analysis of the relationship between corporate social and financial performance. Available at SSRN. doi:10.2139/ssrn.1866371

Mariel, P., Meyerhoff, J., \& Hess, S. (2013). Using a latent variable choice model to capture heterogeneous attitudes and preferences toward the landscape externalities of wind power generation. In International choice modelling conference 2013. Sydney.

McFadden, D. (1974). Conditional logit analysis of qualitative choice behavior. In P. Zarembka (Ed.), Frontiers of econometrics (pp. 105-142). New York, NY: Academic Press.

McFadden, D. (1986). The choice theory approach to market research. Marketing Science, 5, 275-297.

McFadden, D. (1999). Rationality for economists? Journal of Risk and Uncertainty, 19, 73-105.

Michelon, G., Boesso, G., \& Kumar, K. (2013). Examining the link between strategic corpo- rate social responsibility and company performance: An analysis of the best corporate citizens. Corporate Social Responsibility and Environmental Management, 20, 81-94. doi:10.1002/csr.1278

Mohr, L. A., Eroglu, D., \& Scholder Ellen, P. (1998). The development and testing of a measure of skepticism toward environmental claims in marketers' communications. The Journal of Consumer Affairs, 32, 30-55.

Mohr, L. A., \& Webb, D. J. (2005). The effects of corporate social responsibility and price on consumer responses. Journal of Consumer Affairs, 39, 121-147. doi:10.1111/j.17456606.2005.00006.x

Moosmayer, D. C. (2012). Negativity bias in consumer price response to ethical 
information. Business Ethics: A European Review, 21, 198-208. doi:10.1111/j.14678608.2011. 01647.x

Morikawa, T., \& Sasaki, K. (1998). Discrete choice models with latent variables using subjec- tive data. In J. D. Ortu' zar, D. A. Hensher, \& S. Jara-Diaz (Eds.), Travel behaviour research: Updating the state of play (pp. 435-455). Oxford: Pergamon.

Nielsen. (2014, June 17). Doing well by doing good. Retrieved from http://www.nielsen.com/us/ en/insights/reports/2014/doing-well-by-doing-good.html. Accessed on July 25, 2014.

Oberseder, M., Schlegelmilch, B. B., \& Gruber, V. (2011). "Why don't consumers care about CSR?": A qualitative study exploring the role of CSR in consumption decisions. Journal of Business Ethics, 104, 449-460. doi:10.1007/s10551-011-0925-7

Oberseder, M., Schlegelmilch, B. B., \& Murphy, P. E. (2013). CSR practices and consumer perceptions. Journal of Business Research, 66, 1839-1851. doi:10.1016/j.jbusres.2013. 02.005

Odou, P., \& de Pechpeyrou, P. (2011). Consumer cynicism. European Journal of Marketing, 45, 1799-1808. doi:10.1108/03090561111167432

Orlitzky, M., Schmidt, F. L., \& Rynes, S. L. (2003). Corporate social and financial performance: A meta-analysis. Organization Studies, 24, 403-441. doi:10.1177/01708 40603024003910

Paix, L., Bierlaire, M., Cherchi, E., \& Monzon, A. (2011). How urban environment affects tra- vel behaviour? Integrated choice and latent variable model for travel schedules. In International choice modelling conference 2011. Yorkshire.

Paulhus, D. L. (1984). Two-component models of socially desirable responding. Journal of Personality and Social Psychology, 46, 598-609. doi:10.1037//0022-3514.46.3.598

Paulhus, D. L. (2002). Socially desirable responding: The evolution of a construct. In H. I. Braun, D. N. Jackson, \& D. E. Wiley (Eds.), The role of constructs in psychological and educational measurement (pp. 49-69). Mahwah, NJ: Erlbaum.

Pauls, C. A., \& Crost, N. W. (2004). Effects of faking on self-deception and impression management scales. Personality and Individual Differences, 37, 1137-1151. doi:10.1016/ j.paid.2003.11.018

Peloza, J. (2009). The challenge of measuring financial impacts from investments in corporate social performance. Journal of Management, 35, 1518-1541. doi:10.1177/0149206309 335188

Peloza, J., \& Papania, L. (2008). The missing link between corporate social responsibility and financial performance: Stakeholder salience and identification. Corporate Reputation Review, 11, 169-181. doi:10.1057/crr.2008.13

Peloza, J., \& Shang, J. (2011). How can corporate social responsibility activities create value for stakeholders? A systematic review. Journal of the Academy of Marketing Science, 39, 117-135. doi:10.1007/s11747-010-0213-6

Pirsch, J., Gupta, S., \& Grau, S. L. (2007). A framework for understanding corporate social responsibility programs as a continuum: An exploratory study. Journal of Business Ethics, 70, 125-140. doi:10.1007/s10551-006-9100-y

Pomering, A., \& Dolnicar, S. (2008). Assessing the prerequisite of successful CSR implementa- tion: Are consumers aware of CSR initiatives? Journal of Business Ethics, 85, 285-301. doi:10.1007/s10551-008-9729-9

Porter, M. E., \& Kramer, M. R. (2006). Strategy \& society: The link between competitive advantage and corporate social responsibility. Harvard Business Review, 
84(December), 78-92.

Regoli, R. M. (1976). An empirical assessment of Niederhoffer's police cynicism scale. Journal of Criminal Justice, 4, 231-241. doi:10.1016/0047-2352(76)90005-2

Reynolds, W. M. (1982). Development of reliable and valid short forms of the MarloweCrowne social desirability scale. Journal of Clinical Psychology, 98, 119-125.

Ricks, J. M. (2005). An assessment of strategic corporate philanthropy on perceptions of brand equity variables. Journal of Consumer Marketing, 22, 121-134. doi:10.1108/ 07363760510595940

Roberts, J. A. (1996). Will the real socially responsible consumer please step forward? Business Horizons, 39(1), 79-83. doi:10.1016/S0007-6813(96)90087-7

Roth, M., \& Herzberg, P. (2007). The resilient type: Simply the best or merely an artifact of social desirability? Psychology Science, 49, 150-167.

Schro" der, M. J. A., \& McEachern, M. G. (2005). Fast foods and ethical consumer value: A focus on McDonald's and KFC. British Food Journal, 107, 212-224. doi:10.1108/ 00070700510589503

Sen, S., \& Bhattacharya, C. B. (2001). Does doing good always lead to doing better? Consumer reactions to corporate social responsibility. Journal of Marketing Research, 38, 225-243. doi:10.1509/jmkr.38.2.225.18838

Skarmeas, D., \& Leonidou, C. N. (2013). When consumers doubt, watch out! The role of CSR skepticism. Journal of Business Research, 66, 1831-1838. doi:10.1016/j.jbusres.2013. 02.004

Sobol, J. J. (2010). Social ecology and police discretion: The influence of district crime, cyni- cism, and workload on the vigor of police response. Journal of Criminal Justice, 38, 481-488. doi:10.1016/j.jcrimjus.2010.04.017

Stanaland, A. J. S., Lwin, M. O., \& Murphy, P. E. (2011). Consumer perceptions of the antecedents and consequences of corporate social responsibility. Journal of Business Ethics, 102, 47-55. doi:10.1007/s10551-011-0904-Z

Steenkamp, J.-B. E., de Jong, M. G., \& Baumgartner, H. (2010). Socially desirable response tendencies in survey research. Journal of Marketing Research, 47, 199-214. doi:10.1509/jmkr.47.2.199

Stöber, J. (2001). The social desirability scale-17 (SDS-17). European Journal of Psychological Assessment, 17, 222-232. doi:10.1027//1015-5759.17.3.222

Strahan, R., \& Gerbasi, K. C. (1972). Short, homogeneous versions of the MarlowCrowne Social Desirability Scale. Journal of Clinical Psychology, 28, 191-193. doi:10.1002/ 1097-4679(197204)28:2 < 191::AID-JCLP2270280220 > 3.0.CO;2-G

Strahilevitz, M. (1999). The effects of product type and donation magnitude on willingness to pay more for a charity-linked brand. Journal of Consumer Psychology, 8, 215-241. doi:10.1207/s15327663jcp0803_02

Sudbury Riley, L., Kohlbacher, F., \& Hofmeister, A. (2012). A cross-cultural analysis of pro- environmental consumer behaviour among seniors. Journal of Marketing Management, 28, 290-312.

Temme, D., Paulssen, M., \& Dannewald, T. (2008). Incorporating latent variables into discrete choice models - A simultaneous estimation approach using SEM software. Business Research, 1, 220-237.

Thurstone, L. L. (1927). A law of comparative judgment. Psychological Review, 34, 273286. doi:10.1037/h0070288

Tourangeau, R., \& Yan, T. (2007). Sensitive questions in surveys. Psychological Bulletin, 133, 
859-883. doi:10.1037/0033-2909.133.5.859

Tudela, A., Nurul Habib, K. M., Carrasco, J. A., \& Osman, A. (2011). Incorporating the explicit role of psychological factors on mode choice: a hybrid mode choice model. In International choice modelling conference 2011. Yorkshire.

Turner, J. H., \& Valentine, S. R. (2001). Cynicism as a fundamental dimension of moral decision-making: A scale development. Journal of Business Ethics, 34, 123-136. doi:10.1023/A:1012268705059

Vallaster, C., Lindgren, A., \& Maon, F. (2012). Strategically leveraging corporate social responsibility. California Management Review, 54, 34-60. doi:10.1525/cmr.2012.54.3.34

Valor, C. (2008). Can consumers buy responsibly? Analysis and solutions for market failures.

Journal of Consumer Policy, 31, 315-326. doi:10.1007/s10603-008-9070-9

Van de Mortel, T. F. (2008). Faking it: Social desirability response bias in self-report research.

Australian Journal of Advanced Nursing, 25, 40-48.

Vishwanathan, P. (2010). Elusive relationship between corporate social and financial perfor- mance: Meta-analyzing four decades of misguided evidence. In Academy of management proceedings (pp. 1-7). doi:10.5465/AMBPP.2010.54493634

Vlachos, P. A., Tsamakos, A., Vrechopoulos, A. P., \& Avramidis, P. K. (2008). Corporate social responsibility: Attributions, loyalty, and the mediating role of trust. Journal of the Academy of Marketing Science, 37, 170-180. doi:10.1007/s11747-008-0117-x

Vogel, D. (2005). The market for virtue: The Potential and limits of corporate social responsibil- ity. Washington, DC: Brookings Institution Press.

Walker, J. (2001). Extended discrete choice models: Integrated framework, flexible error struc- tures, and latent variables. $\mathrm{PhD}$ dissertation, Massachusetts Institute of Technology.

Walker, J., \& Ben-Akiva, M. (2002). Generalized random utility model. Mathematical Social Sciences, 43, 303-343. doi:10.1016/S0165-4896(02)00023-9

Warner, S. (1965). Randomized response: A survey technique for eliminating evasive answer bias. Journal of the American Statistical Association, 60, 63-69.

Webb, D., \& Mohr, L. (1998). A typology of consumer responses to cause-related marketing: From skeptics to socially concerned. Journal of Public Policy \& Marketing, 17, 226-239.

Wu, M. (2006). Corporate social performance, corporate financial performance, and firm size: A meta-analysis. Journal of American Academy of Business, 8, 163-171. 